\section{THE TAY BRIDGE}

THE new bridge across the Tay, at Dundee, recently completed according to the plans of $\mathrm{Mr}$. Bouch, M.I.C.E., by Hopkins, Gilkes, and Co., of Middlesborough, is the longest structure of its kind in the world. What renders it more remarkable than its enormous size even is the originality in its conception and mode of execution, the result of which has been a structure of great stability and comparatively small cost. Popular accounts of the work have appeared in various publications during its progress and since its completion; but there are various scientific aspects of the undertaking which have not been adequately described. The present article will refer to such technical details as may be of value to those who study the application of scientific principles to industrial ends.

The new methods employed in the construction of the Tay Bridge cannot any longer be regarded as experiments. The severe tests imposed by the Government Inspector and by a heavy traffic uninterrupted during several months removed all uncertainty as to their success and make them of greater value. We may now therefore speak of the details of the structure, so far as these are based on scientific principles, with confidence, seeing that the trial of the bridge may now be regarded as conclusive.

The bridge consists of 85 spans varying in length from 27 to 245 feet. Beginning on the south side there are first 3 spans of 67 feet, then 2 of 88 , then ro of 130 , then 13 of I $45, I_{3}$ of 245 , I of 162 , I I of 130,25 of 69 , I of 170 , and 6 of 27 feet. The direction of the approaches on both sides made it necessary to introduce a curve of $I, 320$ feet radius at each end of the bridge; that on the north side extending over $88^{\circ}$, and that on the south over $16^{\circ} 30^{\prime}$, the central part of the bridge, 7,960 feet long, being straight. Of the thirteen 245 feet spans, 7 are level, and placed so high that they offer a clear water-way of 88 feet at high water. From these northwards, a slope of $\mathrm{I}$ in 73 brings the structure to the required height to join the land line, while southward an incline of $\mathrm{I}$ in 365 serves the same purpose. In order to gain as much clear height as possible in the channel used for navigation, the roadway is laid on the bottom of these large spans, the trains running between the girders, while on the other parts of the bridge, with the exception of the 170 -feet span on the north side, the sleepers are fastened on the top of the main girders.

\section{Nature of the River and its Bottom.}

The Tay is a tidal river about two miles wide at the site of the bridge. The rise and fall of the tide in ordinary spring tides amounts to about is feet, but local circumstances affect this height to a great extent, the difference between the observed and the computed heights sometimes amounting to 3 feet. The strength of current is about five knots per hour. Fig. I shows the depth of the water and the nature of the river bottom. The greatest depth is found between piers I 5 and 20 , but a bank a short distance above the bridge closes up what otherwise would be the best channel for navigation. The rocks on both sides consist of trap. At the south side they rise abruptly to a height of 53 feet, the base being washed by the flood-tide. The river bed to 100 yards out from the south shore is composed of gravel overlaying blue clay with beds of peat and large layers of decayed hazel nuts which at one time grew in abundance near the site of the bridge. Further out the gravel gets coarser, and boulders are found on the river bottom. The trap rock disappears at pier 5 , and its place is taken by red sandstone with a rather worn surface. At pier 20 the surface soil consists of sand, and continues to do so to within a few yards of the north side of the river. The sandstone has a northerly dip increasing at pier 15 , and from this point northward to pier 78 rock is not any longer found at a depth which makes it available for foundation.

The old river-bed, consisting of gravel and clay, continues, however, almost level along the whole line of the bridge. The sand overlaying it is very sharp and pure and contains a large number of shells. Underneath the gravel is a mixture of sand and clay. From pier 70 northward layers of peat and decayed wood are often found in the sand.

\section{Plan for the Foundations.}

The following plan was followed for the foundations :From pier No. I to No. I4 the rock had to be reached, the weight per square foot of surface amounting to eight tons. Piers No. 15 to No. I9 consist of a caisson sunk only a few feet into the bottom, and then piled, each pile having to carry a weight of twenty-five tons. Piers No. 20 to No. 80 are founded on the gravel layer, the pressure per square foot being about two tons. Thence to the north shore the piers rest again on rock.

\section{General Description of Piers.}

Before describing the modus operandi adopted in building the bridge it will be well to give a short description of the piers. The first three commencing from the south side have a rectangular section. At the base they are 14 feet 6 inches by 7 feet 6 inches, and at the top $I I$ feet 6 inches by 4 feet 6 inches. The clay is excavated at low water, and the rock levelled. A concrete foundation is put in, and on these the piers are erected solid in brick and cement. On the top they have a cope of stone 15 inches in thickness, and on this rest the bed plates and girders. For piers No. 4 to No. 14 two cylinders having at the base a diameter of 9 feet 6 inches are placed at a distance of 12 feet, centre to centre, and connected by a web wall 2 feet 6 inches thick. Under water they consist of brick tubes surrounded by a cast-iron casing $\mathrm{I}$ inch thick, the centre of each cylinder and the common base being filled up with concrete. Above water the diameter is 8 feet 6 inches below and 6 feet 6 inches on the top, and they are finished off with a course of stone in the same manner as the first three. From piers Nos. I 5 to 58 the work above high water consists of iron columns varying in diameter from 12 to 20 inches, and having a thickness of metal of I inch. These are braced together by horizontal and diagonal bracings and filled with cement to prevent interior corrosion. In the under water work they differ widely according to the nature of the river bottom and the weight they have to sustain. For those from I 5 to I9 a malleable iron caisson Io feet high, oval in shape with a major axis of 23 feet, and a minor axis of I6 feet is provided with a lining of brick-work 9 inches thick and sunk a few feet into the river bottom. Forty piles are then driven inside as far as a one-ton ram falling from a height of to feet will drive them. The depth to which they penetrate varies from I 5 to 20 feet. These piles are cut off 3 feet above the ground, and the caisson is filled up level with concrete. On top of this concrete a hollow brick pier, hexagonal in shape, is placed, and the space inside up to low water is also filled with concrete. From low to high water the concrete is replaced by solid brickwork, and a course of stone brings the height of these piers to 5 feet above high water. Piers Nos. 20 to 27 are constructed by joining two 15 -feet diameter cylinders above low water, after. sinking them through the sand to the gravel bed. They are then carried up in the same manner as described for I5 to 19. The fourteen piers supporting the thirteen large spans have a $3 \mathrm{I}$-feet malleable iron cylinder with a lining of brickwork I4 inches thick, and are sunk to the gravel layer, and of such height that after reaching the solid bottom their top is slightly projecting above the river bottom. They are then filled in with concrete, and a brick block corresponding in shape with those used for the other piers, but of grenter dimensions, 
measuring 27 feet in the longest, and 16 feet in the has a cope 5 feet thick. For the I62 and I30 feet spans transverse direction, is put on the foundation, filled with on the north side the construction is similar to that concrete, and carried up solid to high water, where it adopted for piers 20 and 27 , while the shorter spans in

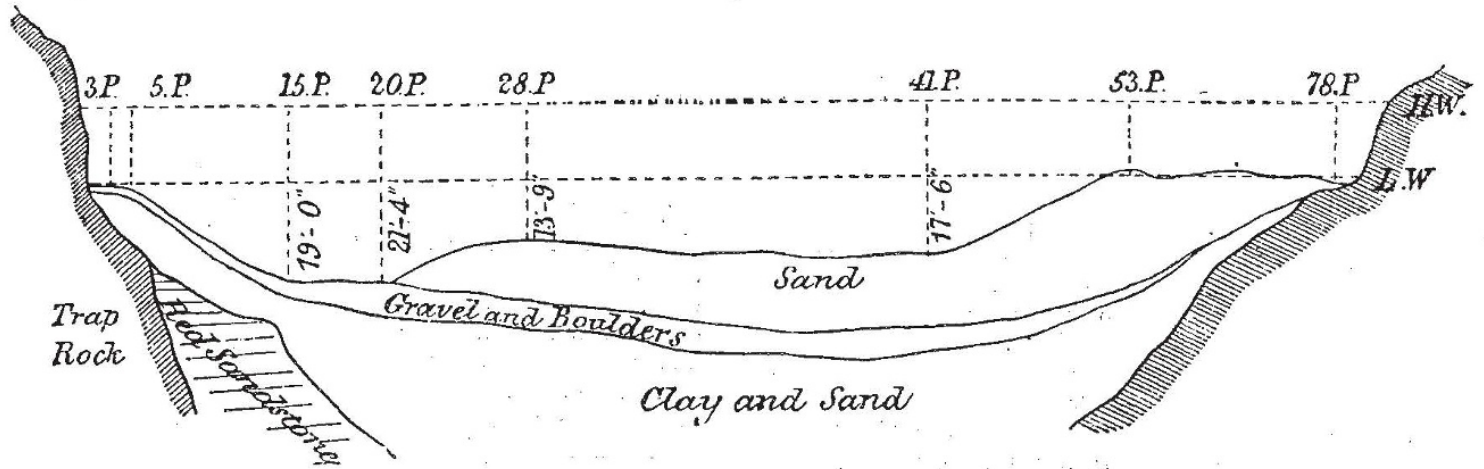

Fyg. I.-Section of river. For..ental scale 2,c00 feet $t 2 x$ inch. Vertical scale 50 feet to $x$ inch.

the curve are supported by columns set in 6-feet cylinders sunk to the required denth and filled up with concrete.

\section{No Staging to be Used in the Construction.}

The change in the nature of the river bottom, the great height at which the bridge had to be constructed and the heavy gales which are prevalent in this part of the country made it necessary from the beginning to depart from the rules generally laid down for the construction of such works. The erection of scaffolding and staging was by these circumstances rendered impossible ; and a series of operations were substituted for these old methods which by their success proved to be great improvements, and must have great interest to engineers and others less directly connected with such

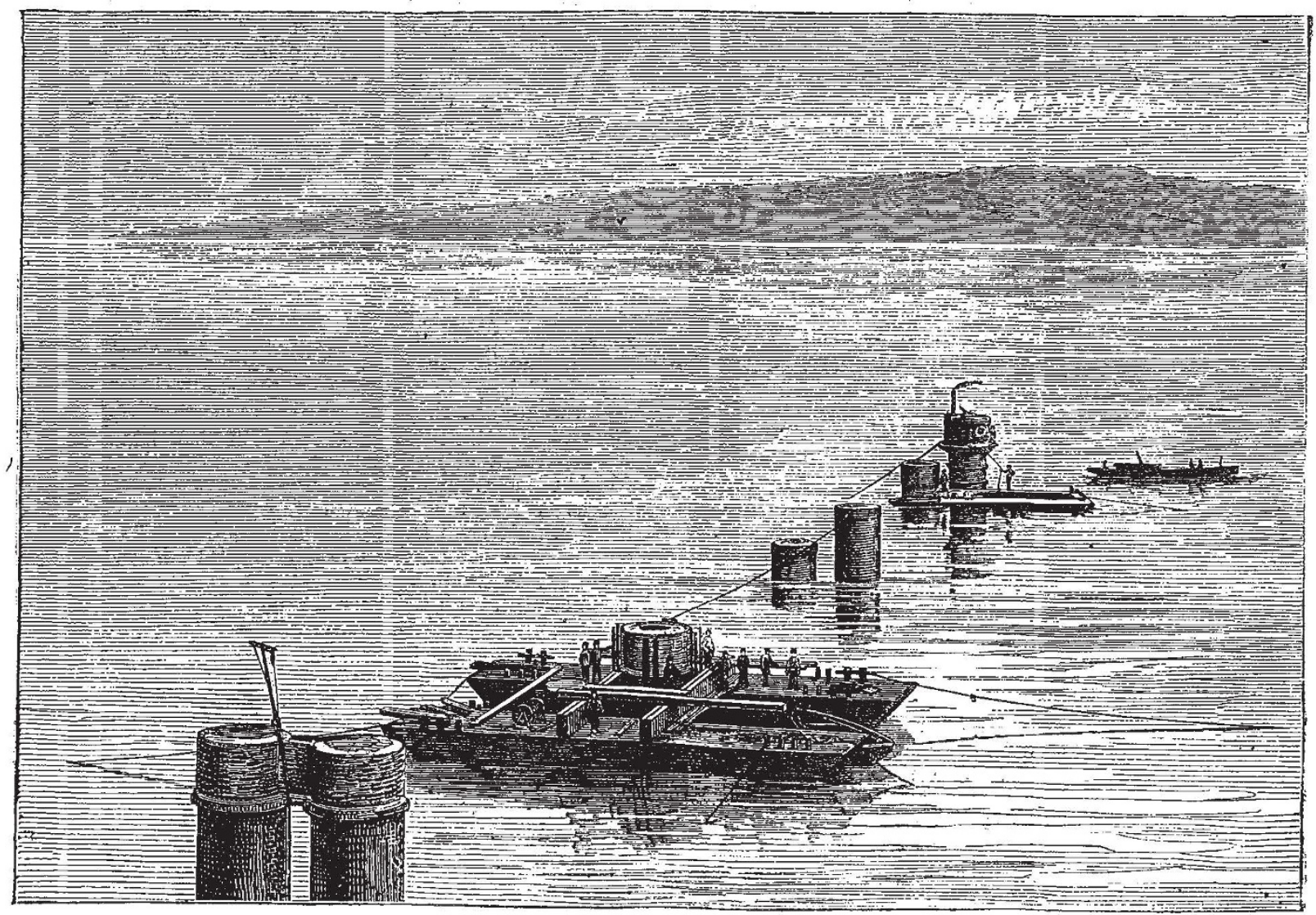

Fils. 2.-Floating and sinki.2g p.ers.

undertakings. As a rule the building operations were entirely conducted on shore, and for this purpose it was necessary to make preparations which took up the best part of the first year. In addition to the ordinary landing jetties, workshops, and stores, special arrangements had to. be made for building the piers and erecting the girders in. 
such a manner that they could be transported to their permanent places without great difficulty. Level foundations of concrete and stone were constructed on the foreshore, some of which were used to put together and rivet the iron caissons forming the outer shell of the piers, others to build the brick work for that part of the piers between the river bottom and low water.
Building and Floating the 9-feet 6-inch Cylinders. After the caissons had been put together and the brickwork built in, they were floated between barges to the point where they had finally to form part of the structure.

The apparatus employed for lifting them consisted of a system of iron girders resting on barges. Flat bars or links having $2^{\prime \prime}$ holes $12^{\prime \prime}$ apart, connected the base of the

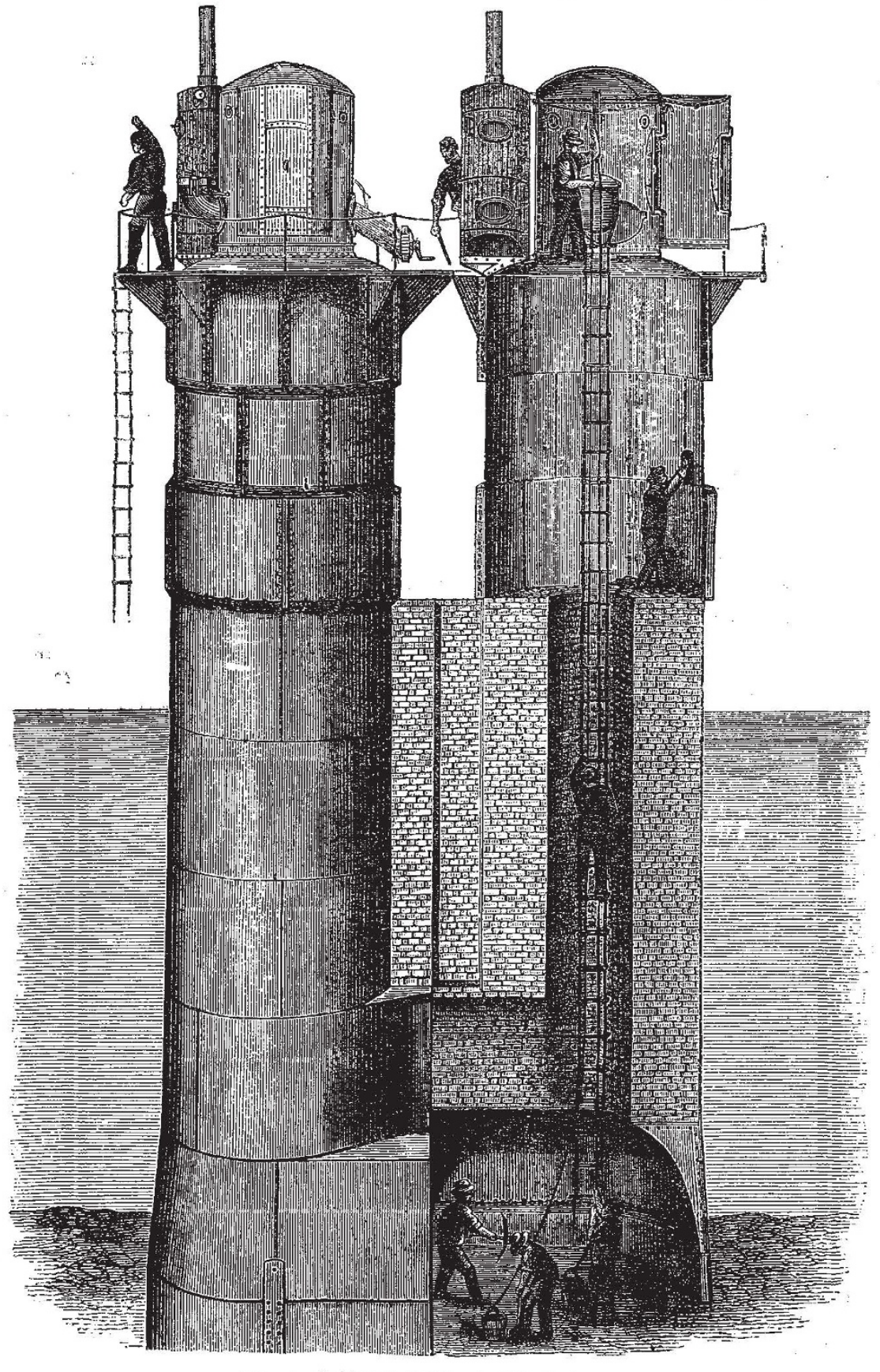

Fig. 3.-Sinking of piers by compressed alr.

piers with hydraulic rams placed on these girders. The / rose again it lifted the barges, and with them the pier, weight could either be taken on the girders direct or on hanging between them off its resting-place, when it could the rams. At high water the girders were floated over without difficulty be towed to its destination, where the top of the piers, and after the tide had receded, and the base was accessible, the conncction between the lifting links and the base of the cylinder was made. As the tide previously moorings had been prepared for it. For this operation it was of course necessary to have a tolerably calm day, and as the weather in the Tay is subject to very 
rapid changes, the operation was sometimes interrupted and frequently endangered by sudden gales, it becoming necessary to take the piers away from the place where it was intended to lower them, and as they could not be placed back in the same position they had to be taken to Dundee Harbour for shelter. The weight of these piers was about Ioo tons, and the carrying barges were 60 feet long by 12 feet wide, and 6 feet deep. If the weather continued favourable, the work of lowering took place the same tide. For this purpose the rams were pumped up $12^{\prime \prime}$ while the weight was on the steel pins resting on top of the girders. The connection between the rams and the links was then made, whereupon a few additional strokes relieved the lower pins of the weight, so that they could be withdrawn and inserted in the next hole. By allowing the water to leave the rams, the pier would of course be lowered till the weight came again on the lower pins, after which matters were in the same position as at the beginning, and the operation could be repeated, and the pier lowered foot by foot.

No great attention was paid to the position of the pier till it neared the river bottom. Then, however, an observer with a theodolite placed on shore or on an adjacent pier, directed the men at the capstans placed on the barges to draw them to such a position as to have the pier exactly in line, while double steel wires, of which the length had been carefully determined, gave the distance from the pier previously placed in position. As soon as the position was in every respect satisfactory the lowering was proceeded with quickly, and it became in this manner possible to put a pier very nearly in its right place. Especially in the curve this work required great attention and care, but it has admirably succeeded. After disconnecting the links which joined the lifting girders to the piers the rising tide would float these with the barges over the top, leaving the cylinder standing on the river bottom, Fig. 2 shows one of these cylinders moored in the river and the general arrangements for floating and lowering. Another of the piers is ready to $5^{\prime}$ above high water, and others are in progress. One has the pneumatic apparatus placed on it.

In most cases the ground was sufficiently level, in others divers had first to clear the bottom of boulders, and in three cases even this was not found effectual, and the settling of the pier on one side caused it to upset. The fallen mass had to be lifted out of the road and broken up as it would have been too costly to set it on end again. Special struts to prevent the possibility of a recurrence of such disasters were then introduced. Two iron tubes of seven and eight inches diameter respectively slid into each other by means of a stuffingbox like the parts of a telescope. The upper end of the top part was fastened to the top of the pier and connected with a pump, the lower part had a mushroom-like base, and when this part was pulled away from the pier under an angle and then water pumped in it took a firm hold in the ground. Four of these struts applied to each pier held it perfectly in position as long as the water pressure was not withdrawn from them. In the subsequent operation of sinking the pier the cocks giving egress to the water were left open, and as long as the motion of the pier was a vertical one the water would escape from all four struts in a gentle flow. As soon, however, as the pier went out of the perpendicular the strut on that side would eject a stronger stream of water, and the man in attendance had only to shut the cock pertaining to that strut to make it answer its purpose of supporting the pier on the side to which it was inclined to fall. This apparatus fully answered the purpose for which it was constructed.

\section{Sinking by the Pneumatic Process.}

In order to sink the piers through the layer of clay overlying the rock the pneumatic process was employed. Tem- porary castings were added to the top of the pier bringing the latter above the highest water, and a malleable iron air-bell, having the usual air-lock for the passage of the workmen, and smaller locks for the passage of excavating material to the outside or concrete to the inside was placed on the top (Fig. 3). A six horse-power steam-engine, connected with an air-pump, supplied the air by the pressure of which the bottom of the pier was kept dry. The breathing of the men and the burning of candles required, of course, a more liberal supply than would have been necessary for the first purpose only. Instead of allowing this surplus to escape at the bottom of the pier it was used to drive a pneumatic hoist lifting the excavated materials up to the air-lock.

As the excavations proceeded, the pier would sink down till it reached the rock, and this movement was facilitated by the bottom of the pier being slightly conical. The rock was then levelied down by pick-axes and chisels so as to give a firm bearing, and concrete material introduced filling up the bottom chamber and the shafts which had been left in the brick-work for the passage of the men. When this work had proceeded to above low-water, the temporary castings and air-bells were removed and the pier built up between low and high water in the usual manner from a barge.

This process, though slow and costly, worked on the whole satisfactorily, so far as the piers were founded upon rock. It was carried through without many accidents, though one occurred in which six men unfortunately lost their lives. On a stormy day in August, I873, a barge loaded with coals, moored near one of the piers in process of sinking, probably knocked against the structure and must have damaged the iron-though it was not observed at the time--to such an extent that at the next high tide, when the air pressure was greatest, one of the top plates was blown out, the water rushing in from both top and bottom, and of courze making escape an impossibility.

\section{Piled Pierss.}

The oval caissons for piers Nos. I6 to I9, were built, and floated out in precisely the same manner, and then excavated under water by a diver (the excavated substance being hoisted up from a barge) and sunk 2 feet into the ground. A staging constructed of angle iron was then floated out and put over this caisson, and was used as a support for the pile driver. The piles had a length of 60 feet. The depth at the highest tide was 45 feet, and it was therefore possible to drive them I 5 feet into the ground, before any means of lengthening them for the purpose of driving, had to be adopted. Divers were engaged to cut them under water, leaving 3 feet standing in the caisson. Concrete lowered in large buckets, which only opened when getting to the bottom, surrounded and covered the heads of the piles, the height of the concrete being 7 feet above these heads. During all these operations the caisson extended temporarily to above high water, so that the diver could continue his operations during the whole of the tide, notwithstanding the strong current, and the danger of washing the essential parts of the concrete away was considerably lessened. An inspection, undertaken for the purpose of ascertaining how far the latter had been successful, gave very satisfactory results, the whole mass of the concrete being found perfectly hard after a few days. The disconnection of the temporary caisson from the lower part, and floating away in the same manner as that by which it had been brought out was a work of little difficulty.

The floating out and fixing of the brick pier which was put on top of this concrete foundation will be described more fully with the operations necessary to complete the large piers. These are certainly the most interesting ones on account of their magnitude, although this very size may have been the means of avoiding particular difficulties which stood in the way of the work connected with the 
smaller piers. It has been found throughout the operations that in a river subject to such vicissitudes as the Tay, the handling of a very heavy mass is a far less intricate and difficult matter than that of lighter weights, and during the execution of the work connected with the larger spans the operations were not in the least interrupted by weather which would have been absolutely fatal to the smaller piers.

\section{Work on the 245-feet Span Piers.}

The under-water work of the large piers can be conveniently divided into three parts: that of building, floating, and sinking the caisson; that of building, floating, and fixing the brick pier; and that of bringing it up to the required height five feet above high water. The first two are, of course, by far the most important. The lower caisson consisted of $\frac{3}{8}$ inch malleable iron plates riveted together so as to form $3 \mathrm{I}$ feet cylinders 20 feet high. After erecting this structure on the foundation on the foreshore prepared for it, a lining of brickwork I4 inches thick was built inside. This lower part was to form part of the permanent structure. On top of it and connected with it by a bolted horizontal joint, another length of plates was built bringing the whole up to 40 or 44 feet of height, according to the depth of water. This top part merely served a temporary purpose, and in order to resist the effect of the waves and current it was provided with angle iron stiffeners to a far greater extent than the permanent part, which derived sufficient stiffness from its lining of brickwork.

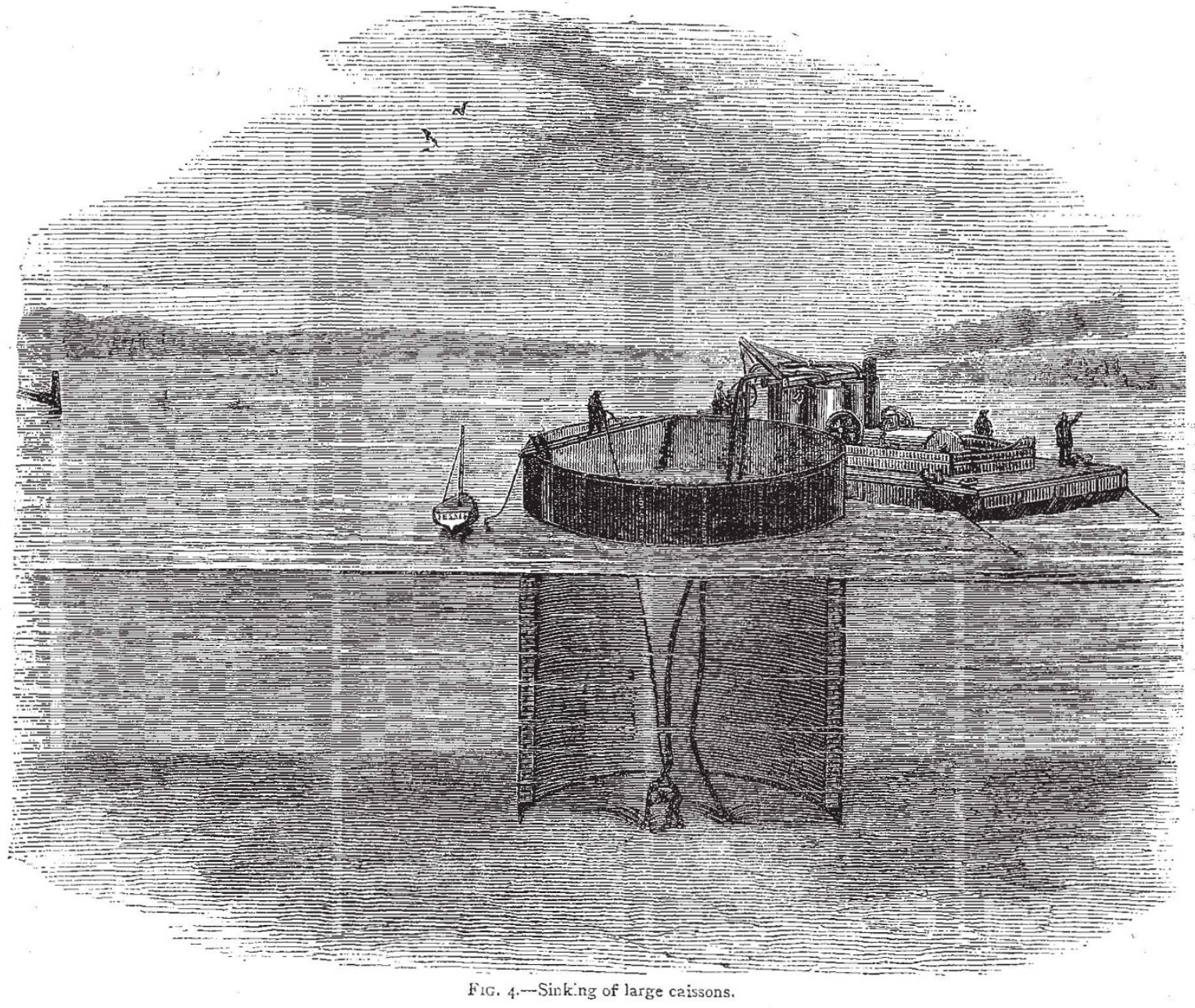

At four points of the circumference $T$ iron sirips ran vertical from top to bottom, and were riveted to the caisson. In these strips or links there occurred three and a quarter inch holes at intervals of $I$ foot, and by putting steel pins of slightly smaller diameter through these holes, it became possible to obtain a hold with the hydraulic rams by means of a girder with a claw-like end placed on their tops. The hydraulic rams were placed on the four corners of a square system of girders having projecting ends for the barges. On the under-side of these girders a claw similar to that found on the top of the rams made it possible to take the weight of the pier either on the four lower claws, or the four top claws, which were connected with the hydraulic rams.
Two pontoons, each 70 feet long, 20 feet wide, and 7 feet deep, lifted the weight of girders and the piers standing in between them off the ground by means of the lower claw. It was then floated out; and so powerful was the resistance which the heavy mass, weighing about 200 tons, offered to the current, that two strong tug steamers had to be employed for this purpose. Arrived at its destination, it was securely moored. The first one floated in this manner had to withstand the fury of a three days' gale, during which it had to be left out in the river, the waves washing right over the barges, the hatchways having been nailed and caulked to keep the water out.

To lower the caisson the rams were pumped up I2 inches and the steel pin which connected the upper claw 
with the caisson inserted. By pumping up again the weight was taken off the lower claw, the pin which had held it there withdrawn and inserted in the hole a foot higher up. The water was then allowed to flow out of the rams and the weight to come down on the lower pin again, during which operation the caisson had necessarily been 12 inches lowered. The work of adjusting it in its right place was accomplished in the same manner as described for the smaller piers. The first of these caissons was lowered down on August 28, I 875 , and the same afternoon the floating girders and barges were withdrawn, and the pier left standing on the sandy bottom. The tide was particularly strong, and from the resistance which this mass offered to its flow washed away the sand round about it, thereby causing the pier to heel over to such an extent that next morning it was more than 6 feet out of level. The centre of gravity of these piers, compared to the diameter of the base was, however, so low that no serious apprehensions were felt, and when the sand was excavated on the high side it soon came to the level again. It was always found possible with a little care to keep the pier nearly level in sinking by excavating on one side or another, and no such artificial means of keeping them upright, as had been adopted in the case of the smaller piers, became necessary.

\section{Sinking the Large Caissons.}

The best means of excavating the sand out of these piers had been a subject of very careful consideration, and numerous experiments had been tried with varying results, in order to find the best machinery for effecting that purpose. Finally, however, an apparatus constructed upon very simple principles by Mr. Reeves, one of the contractor's assistant engineers, was found the most efficient. The conditions which it had to fulfil were of this kind. It had to elevate the sand from the inside of the cylinder and drop it outside at a small cost, and it had to be constructed in such a manner as to be easily detached from the pier in case of a sudden gale. These conditions were fulfilled by placing the whole apparatus on a barge which could be moored alongside the pier and withdrawn with little trouble and at a moment's notice. On this barge were placed four air-tight tanks each having a circular hole in the bottom, closed by a door on which an india-rubber ring was fastened so as to obtain an air-tight closing. A steam-engine worked two exhaust ait-pumps, and each of these pumps was so connected with two of the tanks that by means of a three-way cock either the one or the other could be put in communication with it. From the top of the tanks flexible pipes of 4 inches diameter ran down to the bottom of the pier, and their ends were in charge of the diver, who could direct them. Either of these tanks being put in communication with the pump would be exhausted, and a current of water mixed with sand would rush up the flexible hose, filling up the vacancy. A float indicated the height to which a tank was filled, and before any water or sand could enter the air-pipe and reach the valves, the attendart had to turn the cock which brought the other tank into communication with the exhaust-pump and admitted air into the full one. It then discharged its contents through a hole in the bottom of the barge into the river. The joints of the cylinder not being water-tight, the level of the water inside was always as high as that outside, and the only purpose of the temporary caisson was to protect the divers from the strong current, and give those in charge of the operation an opportunity of observing the position of the pier during its descent. Fig. 4 shows this apparatus at work by one of the large piers.

\section{Building the Brick part of the Pier.}

It will be understood that by the sinking of this caisson a hole was formed in the sand, the sides of which were kept up vertically by the caisson while the bottom was formed by the hard gravel layer. This pit was now filled with concrete to a couple of feet above the river bottom, and all the iron above that point removed. The concrete hardening became like a rock with a level surface of $3 \mathrm{I}$ feet diameter. The remaining part of the pier up to high water consisted of brickwork only. The lower portion was built on a level part of the foreshore in bricks and Portland cement, which became so hard that the block could be lifted from four points by means of barges and apparatus similar in all but the dimensions to that used for the floating of the $9^{\prime} 6^{\prime \prime}$ piers. Previous to the building a layer of paper was spread on the temporary foundation in order to prevent the brickwork from adhering to it. The block was hexagonal in shape, measuring $27 \mathrm{feet}$ in one direction and 16 feet in the other. Its height would depend on the depth of water at the place where it was to be used, and was so regulated that after depositing the block on the artificial rock foundation the top would be a little above low water. The weight of the blocks was about 200 tons. In the centre a hole was left answering a double purpose. First, it allowed the weight of the block to be kept below the point at which it would have become unmanageable and than the concrete which was put in this hole after the block was in situ would increase the adhesion between the brickwork and the foundation.

From low to high water line the pier was finished in solid brickwork set in Portland cement, the work of course being interrupted at every rising tide and taken up again when the water was low enough. Four courses of ashlar of an aggregate thickness of 5 feet brought the pier to the height at which the cast iron columns commenced and the bolts to hold down their bases were fixed in the stone.

\section{Superstructure.}

In the erection of the iron superstructure the same principle of not employing staging in the river was adhered to. The iron-work as it arrived, in pieces of from 20 to 35 feet long, from the contractor's works at Middlesborough, was landed on a jetty near the shore about 260 feet long, over which a strong travelling crane could be moved from end to end. Here the parts were put together and riveted up. All the girders with the exception of the r7o-feet span and the 27 -feet spans, are parallel lattice girders having diagonal struts and ties. The section of the booms is trough-shaped, that of the compression diagonals $\mathrm{H}$-shaped, while the tension bars are flat, varying in thickness from three-eighths to five-eighths of an inch. Those girders which have the roadway on top have half struts running up from the intersections of the diagonals to the top boom, while those where the load is at the bottom have tie-bars for the same purpose. The depth of the 245 feet spans is 27 feet, their width 15 feet, and their weight about 190 tons. In them the rails are carried on longitudinal sleepers resting on iron cross-sleepers 5 feet apart, while in all the other spans wooden sleepers 3 feet apart, and having a section of 12 by 9 inches, carry the roadway.

\section{Floating the Girders.}

When a girder was completely erected and riveted up, parts of the jetty on which it rested were removed at each end, and barges were introduced at a low state of the rising tide in the gaps. As the height of the water increased these barges would touch the under-side of the girders, and a further rise would lift them off the bearings on which they had been erected, and keep them floating on the two pontoons. It will be seen that in order to get the ends of the girder free for depositing them on the piers, it was necessary to keep the barges at some distance from these ends and to introduce temporary vertical struts between those parts of top and bottom boom which rested on the barges. In addition to these struts some others were used to steady the comparatively high and narrow girders on their floating supports in case rough weather should 
occur during the operation. For the different sizes of girders, different jettys and pontoons were used, but apart from this the operation was carried on in the same manner in all cases. But here again it soon became clear that while to carry out the smaller ones in doubtful weather was a dangerous operation, the larger ones were far less liable to disturbance by the weather, and some of them in fact were subjected to a severe trial in this respect, the two tugs on one occasion being unable to tow the structure in the ordinary manner against the strong westerly wind, and breaking all the tow ropes. As soon, however, as additional towing power had been procured, the operation was successfully carried through. Intricate as it seemed to build these heavy girders on shore and tow them to their destination-often more than a mile distant-by the use of plant specially designed for the purpose, the execution became very easy, it seldom taking more than twenty minutes to convey them from the one place to the other.

\section{Lifting the Girders to their Permanent Resting Places.}

The general arrangement of the six columns which have to support the larger spans follows that of the brick piers on which they rest. Four centre columns placed in a square and connected by strong vertical and diagonal bracing, are 15 inches in diameter, and from these centre columns the lifting of the span takes place. Each of the columns is about ro feet long, varying slightly according to the height of the pier, and every second length has brackets cast on to which transverse girders are bolted. The outside columns placed on the point of the pier are I8 inches diameter, and as well as the inside ones $x$ inch thick. Between these outside and inside columns rest the ends of the main girders, the end cross girder and end horizontal bracing having been left out so as not to come in the way of the four central columns and their bracings during the process of lifting. To each vertical end post a T strip is bolted from top to bottom in the same manner as was described for the large caissons. In common with these it has $3 \frac{1}{4}$ inch holes at 12 inches distance. A transverse trough girder of slightly shorter length than the distance between these end posts is placed on the temporary girders connecting the columns, and in this two hydraulic rams, carrying another girder are fastened. By inserting steel pins in the holes nearest to this top girder, and then pumping up, the main span can be raised to such a height as the stroke of the rams will permit, and if at that point pins are put in the holes then nearest to the fixed or lower ram girder and the weight allowed to come down upon these, the rams can be lowered again without letting the main girders down, and by a shifting of the pins to a lower hole, the operation can be repeated, each stroke of the rams causing a rise of the girders of $I$ foot. The motive power is derived from a pump worked by manual labour, the space at disposal not permitting the introduction of steampower for this purpose. The diameter of the pump-plungers must therefore be small, and the movement of the rams consequently a slow one. It was, however, possible to lift 20 feet a day, and during the long days of summer a 40-feet lift has often been reached in 24 hours. Another set of apparatus was kept in readiness on the next lifting girder, and with it operations were continued, when the girder had become too high for the lower ones, which then in their turn were shifted to a higher point. As the girder rose, the bracings connecting the outer columns with the four central ones were put in, and after it had reached its final height a system of girders capable of carrying the bed plates and superstructure were fastened on the top of the columns, and the girder which had been elevated to a few inches above its proper height was lowered down on them. Before this could, however, be done, they had to be connected to the next set of girders, as they were calculated as continuous girders and joined together in sets of four. To make these junctions, one of the ends had to be lifted up from 5 to $6 \frac{1}{2}$ inches, while the junction plates making the top and bottom booms continuous were riveted on. The lowering of the girder at the other end would then produce an initial strain in these junctions and fulfil the requirements of continuity. A good deal of time was required for making these junctions, the junction plates having all to be carefully marked and drilled while the girders were still hanging in the apparatus, and this circumstance in one case led to a disaster which caused great loss and delay. On February 3, 1877, while the work of joining the two southmost of the 245 feet spans was in preparation, a gale of unprecedented severity came down the valley of the Tay with such a fierceness and suddenness that it was even impossible to get near enough to the piers to take off the men who had been at work on them, and they were obliged to seek shelter on one of the adjacent girders which had not been raised. The wind continuing to blow in strong gusts produced violent vibrations in the unbraced ends of the girders and gradually shifted them to the edge of the lifting girders, causing one side to fall when the limit of stability was reached, breaking down the pier and precipitating the other girder in consequence. The fallen girders had to be lifted, cut up, and replaced by new ones, and the work was thereby materially delayed.

\section{Lifting of the 145 Spans.}

The lifting of the 145 spans was accomplished in a somewhat different manner. The hydraulic lifting apparatus was placed on the top of a temporary structure of timber fixed on the cast-iron piers, a few feet higher than the top boom of the girder would be after being raised, and long links with holes a foot apart reached to where the girder stood 5 feet above high water. These girders being so much lighter could be raised to the top in one day, but as the arrangement of the columns was somewhat different from that of the 245 feet piers (the girders resting on the four central columns), they were hoisted while fixed together by temporary transverse bracings, which kept them at a greater distance apart than they would finally be, and hoisting them uxp outside the columns altogether. It was therefore necessary to modify the apparatus to this extent that the girders, after disconnecting the temporary bracing, could be slung in and permanently braced.

The work in connection with this bridge was begun in the summer of $187 \mathrm{I}$, the first stone of the land pier on the south side being laid on July 22 of that year. During the first three years, however, little progress was made, and the operations during that time must be considered as being inore of an experimental nature. From August, 1875, however, the progress was very great, and as the managers and men gained experience, the erection of the structure was proceeded with at a vastly accelerated rate. New workshops, jetties, and appliances of various kinds were added, a foundry erected for the casting of columns, and in September, 1876 , it was found necessary, in order to keep pace with the building of piers and erecting of girders on shore, to work night and day, and the contractor introduced for the first time in Scotland electric light for out-door work. Two lamps, each of 1,000 candle-power, the current for which was generated by Gramme machines, did excellent service. The lamps were placed at right angles to each other, and in this manner they lit up an area of 100 by 500 yards in such a way that every kind of work could be carried on uninterruptedly. This was of great importance for the floating out of piers and girders which had to be done at high water, the preparations commencing three or four hours beforehand, and therefore having sometimes to be made in the early morning. The last pier was in this manner floated out at seven o'clock on the morning of December 26,1876 . 
The bridge was severely tested by Gen. Hutchinson, the Government Inspector of Railways, in February of this year. Five locomotive engines of 72 tons weight each were placed on the large spans and run over them at considerable speed. This weight of 360 tons for each of the $245^{\prime}$ spans will never be reached in the working of the railway, 162 tons being the greatest load resulting on each span from the heaviest goods train. Under the test load the deflection of any of the spans did not exceed the calculated limit, and the lateral movement during the passage of trains was but trifling.

On June I the bridge was opened for ordinary traffic, and it is now daily crossed by numerous and heavy trains. For the North British Railway Company and the travelling public its completion is of very great importance. But the work must have a still greater importance in the eyes of engineers and those interested in the practical application of scientific principles, as many new methods to overcome formidable difficulties were successfully carried out, some of which might with advantage be used in similar structures.

A. GROTHE

\section{THE NORWEGIAN NORTH ATLANTIC EXPEDITION}

THE expedition left Bergen on June I5, and proceeded without interruption to the Westfjord, in Nordland, where we had our first station. A temperature-series was here taken with Negretti and Zambra's new deep-sea thermometer, which showed $10^{\circ} 7 \mathrm{C}$. on the surface, a minimum of $4^{\circ} 4$ in a depth of 40 fathoms, and $6^{\circ} .5$ at the bottom in 340 fathoms. The Vöringen stopped some hours at Tromsö to take on board a pilot, and proceeded to the Altenfjord, where we found $7^{\circ} \cdot 3$ at the surface, a minimum of $2^{\circ} 7$ in a depth of 100 fathoms, and $3^{\circ} 9$ in 220 fathoms at bottom. From Alten we went to Hammerfest, where we stayed two days. Our next stations were in the Porsangexfjord and in the Tanafjord. On all these stations we dredged and trawled with good success. On June 26 we were lying at Wardö, where Capt. Wille made magnetical observations of force and inclination. The declination was determined the day before off the coast by going round with the ship, and taking bearings of the sun on different courses. On June 27 we put to sea on an eastward course. The barometer was falling rapidly, and at midnight the wind and sea got so heavy, that the ship was put with the stem against the wind, and we were lying almost still. This situation lasted till the next night, when we again proceeded on our course, but very slowly, the ship pitching heavily, and the wind being constantly ahead. In this manner we found $0^{\circ} \mathrm{C}$. at the sea bottom, in about $71^{\circ} 30^{\prime} \mathrm{N}$. and $36^{\circ} 30^{\prime} \mathrm{E}$. from Green wich. We then sailed northwards and westwards, and passed the said bottom temperature several times, so that I am now able to give its situation pretty accurately in the chart. The northern part of this zero line forms a bay east of Bear (Cherry) Island, where the warmer water reaches a higher latitude, and runs close to the east side of that island, where we for the first time observed the polar ice. The temperature-series showed the accuracy of Weyprecht's observations, that the colder Polar water edges itself along the bottom from the east and north, and the warm Atlantic water runs out in a similar edge in the contrary direction towards Novaya Zemlya and Franz-Joseph Land. On July 4 we were at Bear Island, on the south-east side. We were happy to find the sky almost perfectly clear, a ratber rare occurrence on this island. The ship was anchored outside the open coast, and we went on shore at the mouth of a little river, in the vicinity of which there stands a hut, which has been the abode of wintering parties. Here we deposited the mail which we brought for the Dutch polar exnedition in the Wilhem Barentz schooner. The place was marked with a flag, and the letters, \&c., dug down, inclosed in an outer wooden and an inner sheet-iron soldered box. I took a tour upon the nearest hills, collected some rock specimens, and measured the altitude of the highest peak on Bear Island, Mount Misery. The calculation gave me a height of 1,787 English feet, a result which I regard as very accurate. After dinner we weighed and proceeded to the south-west; crossed, the following day, the zero line of bottom temperature on the bank between Bear Island and Norway, sounded in 1,024 fathoms on July 6 in lat. $73^{\circ} 6^{\prime} \mathrm{N}$, , long. $11^{\circ} 56^{\prime}$ E.; we went then east-south-eastwards, crosșed again the zero temperature line, and shaped our course for Hammerfest, where we arrived on the 8th. The ship is now cleaned; we take in coal, and expect to be ready to sail on a westward cruise in three days. Our first cruise has yielded thirty-eight soundings, seventeen temperature series, ten dredgings, and seven trawlings, all successful, New species of animals have been found by our zoologists. Negretti and Zambra's newest reversible deep-sea thermometer has done us great service; the instrument has, almost without exception, worked very well. I have constantly compared its readings from the bottom with the reading of the Casella, Bucbanan's improved form, and found a very close agreement. As I supposed, the wooden box which carries the thermometer gets watersoaked after a few experiments in a few hundred fathoms, so that it no longer floats, but this is no drawback, as the lead rushes down so fast that the thermometer always keeps its upright situation till it reaches the bottom, and it never requires more than three minutes for a perfect accommodiation to $O^{\prime} I$ of a degree. I therefore regard this instrument as a very important improvement, and feel much obliged to the inventors and makers.

Hammerfest, July ro

H. MOHN

\section{THE TASTMETER}

TR. EDISON has applied the principle of his carbon telephone to a new instrument which is said to be a measurer of infinitesimal pressure. The principle is the variation of the electric resistance of a carbon button due to variation of pressure, and the instrument is said to be an extremely delicate thermoscope. We have not yet, however, received any authentic account of its performance or of its accuracy, but its ingenuity certainly deserves a description, for which we are indebted to the Scientific Anterican.

It is the outcome of Mr. Edison's carbon telephone. Having experimented with diaphragms of various thicknesses, he ascertained that the best results were secured by using the thicker diaphragms. At this stage, however, he experienced a new difficulty. So sensitive was the carbon button to changes of condition, that the expansion of the rubber telephone handle rendered the instrument inarticulate, and finally inoperative. Iron bandles were substituted with a similar result, but with the additional feature of musical and creaky tones distinctly audible in the receiving instrument. These sounds Mr. Edison attributed to the movement of the molecules of iron among themselves during expansion. He calls them "molecular music." To avoid these disturbances in the telephone, the handle was dispensed with; but it had done a great service in revealing the extreme sensitiveness of the carbon button, and this discovery opened the way for the invention of the new and wonderful instrument.

The micro-tasimeter is represented in perspective in Figs. I and 2, in section in Fig. 3, and the plan upon which it is arranged in the electric circuit is shown in Fig. 4.

The instrument consists essentially of a rigid iron frame for holding the carbon button, which is placed between 